\title{
Hot water treatments improve 'Hass' avocado fruit quality after cold disinfestation
}

\author{
Peter J. Hofman a,*, Barbara A. Stubbings a, Matthew F. Adkins a, \\ Geraldine F. Meiburg ${ }^{b}$, Allan B. Woolf ${ }^{c}$ \\ a Queensland Horticulture Institute, Maroochy Research Station, PO Box 5083, Sunshine Coast Mail Centre, Nambour, \\ Qld. 4560, Australia \\ ${ }^{\mathrm{b}}$ Redlands Research Station, Queensland Horticulture Institute, Department of Primary Industries, PO Box 327, Cleveland, \\ Qld. 4163, Australia \\ ${ }^{\mathrm{c}}$ HortResearch, Mt Albert Research Centre, Private Bag 92 169, Mt Albert, Auckland, New Zealand
}

\begin{abstract}
The potential for hot water treatment (HWT) to improve quality of 'Hass' avocado following cold disinfestation for fruit flies, was investigated. Avocado fruit were placed in water at $38-42{ }^{\circ} \mathrm{C}$ for $20-60 \mathrm{~min}$, disinfested for 16 days at $1{ }^{\circ} \mathrm{C}$, then ripened at $20{ }^{\circ} \mathrm{C}$. In the following season, fruit from another orchard were treated with hot water at $39-42{ }^{\circ} \mathrm{C}$ for $20-30 \mathrm{~min}$, disinfested as above, then ripened at $16{ }^{\circ} \mathrm{C}$. In both seasons, HWT significantly reduced skin damage caused by cold disinfestation, with $40{ }^{\circ} \mathrm{C}$ for $30 \mathrm{~min}, 41{ }^{\circ} \mathrm{C}$ for $20-30 \mathrm{~min}$ and $42{ }^{\circ} \mathrm{C}$ for $25-30 \mathrm{~min}$ giving the greatest reduction. Hot water treatments also reduced body rots in ripe fruit, with 40 and $41{ }^{\circ} \mathrm{C}$ for $30 \mathrm{~min}$ being consistently the most effective. Treatment at $42{ }^{\circ} \mathrm{C}$ increased body rots compared to the other HWTs in one season, and there was no benefit of HWT times longer than $30 \mathrm{~min}$. The severity of vascular browning (VB) and mesocarp discolouration (MD) in ripe fruit was generally low, and increased following cold disinfestation. Hot water treatments reduced VB severity but had no effect on MD. Treatment at $41{ }^{\circ} \mathrm{C}$ for $25-30 \mathrm{~min}$ and $42{ }^{\circ} \mathrm{C}$ for $25 \mathrm{~min}$ increased the percentage of externally acceptable fruit (less than $5 \%$ of the skin area with defects) from 0 to about $80 \%$ 3 days after removal from disinfestation. The same treatment also increased the percentage of ripe fruit with acceptable flesh quality (less than $5 \%$ of the flesh with rots or disorders) from 0 to $16-20 \%$, due mainly to reduced body rots. These results indicate the commercial potential of HWTs of about $41{ }^{\circ} \mathrm{C}$ for $25-30$ min, or $42{ }^{\circ} \mathrm{C}$ for 25 min to improve avocado external and internal fruit quality following cold disinfestation. (C) 2002 Elsevier Science B.V. All rights reserved.
\end{abstract}

Keywords: Avocado; Disinfestation; Hot water; Conditioning; Quality; Chilling injury; Disease; Fruit fly

* Corresponding author. Fax: + 61-7-5441-2235.

E-mail address: hofmanp@dpi.qld.gov.au (P.J. Hofman).

\section{Introduction}

Disinfestation treatments to minimise the risk of insect pests in horticultural produce are required for fruit entry into a number of intra-na- 
tional and international markets. In the past, disinfestation treatments have been based on chemical fumigation and dips. However, many of these treatments have been withdrawn, and safer treatments, mainly using physical methods, are being developed. These have focused on either heat, cold, irradiation, controlled atmospheres, or combinations of several of these (Heather et al., 1996; Chervin et al., 1997; Jacobi and Giles, 1997; Nyanjage et al., 1998; Hallman, 1999).

Avocado fruit from several production areas in Australia require a disinfestation treatment against fruit flies if sold outside these production areas. A cold disinfestation treatment of $1{ }^{\circ} \mathrm{C}$ for 16 days is the approved quarantine treatment for 'Hass' avocados exported to New Zealand, and is an accepted treatment for many fruit fly species (Jessup, 1994). However, skin damage ('chilling injury') results from storage at $1{ }^{\circ} \mathrm{C}$ (Hofman et al., 1998).

Fruit exposure to mild heat can reduce damage during subsequent hot or cold treatments (Klein and Lurie, 1992; Lurie, 1998). This conditioning effect has been demonstrated in tomato (Lurie and Klein, 1992), avocado (Woolf and Lay-Yee, 1997; Woolf, 1997) and mango (Jacobi et al., 1996). Sanxter et al. (1994) examined the viability of using $38{ }^{\circ} \mathrm{C}$ hot air treatments to provide tolerance to low temperature disinfestation treatments of fruit fly in 'Sharwil' avocados. Both hot air and hot water treatments (HWTs) can reduce external skin damage of 'Hass' avocado caused by subsequent heat and cold treatments (Woolf et al., 1995; Florissen et al., 1996; Woolf and Lay-Yee, 1997; Grové et al., 2000). Thus, heat treatments have potential to reduce external damage (or 'chilling injury') of 'Hass' avocados during cold disinfestation.

Hot water treatments can be more easily applied commercially than hot air treatments (lower capital investment), particularly if the duration of treatment is short. Therefore, the following experiments investigated the potential for HWT to reduce damage to 'Hass' avocado fruit during the commercial cold disinfestation treatment of $1{ }^{\circ} \mathrm{C}$ for 16 days. These treatments were tested over two seasons with fruit from several production locations.

\section{Materials and method}

\subsection{Fruit harvest and handling}

For experiment 1, 'Hass' avocado fruit (Persea americana Mill.) were harvested from three commercial orchards (each orchard being a replicate) near Nambour (SE Queensland; lat. 26³7'S, long. $152^{\circ} 56^{\prime} \mathrm{E}$ ) on 21 October 1998 , corresponding to late season harvest for this area (dry matter $=$ $29 \%$ ). Fruit from two of the orchards were harvested in the early morning and transported to the laboratory within $2 \mathrm{~h}$ of harvest. Fruit from the third orchard was harvested the previous day, but otherwise treated the same.

For experiment 2, fruit were harvested from three separate blocks (each block being a replicate) on the same commercial orchard near Bundaberg $\left(25^{\circ} 15^{\prime} \mathrm{S}, 152^{\circ} 30^{\prime} \mathrm{E}\right)$ on 15 April 1999 ('early season'; dry matter $=21 \%$ ).

Fruit were placed in single layer trays after harvest and transported to the laboratory. After HWT (see below), fruit were air-cooled for $2 \mathrm{~h}$, dipped in $0.55 \mathrm{ml} \mathrm{1}^{-1} \operatorname{Sportak}^{\circledR}$ (a.i. prochloraz; $0.05 \% \mathrm{v} / \mathrm{v}$ ) for $30 \mathrm{~s}$, dried, and either ripened or disinfested.

The percent dry matter of the flesh at harvest was determined by combining representative flesh samples of six fruit from each farm or block, and drying to a constant mass at $65{ }^{\circ} \mathrm{C}$.

\subsection{Experiment 1}

Within $4 \mathrm{~h}$ of the latest harvest, fruit were placed into a hot water bath at either 38 or $40{ }^{\circ} \mathrm{C}$ for 30 or $60 \mathrm{~min}$, or at $42{ }^{\circ} \mathrm{C}$ for 20 or $40 \mathrm{~min}$. Approximately $6 \mathrm{~h}$ after treatment, the fruit were placed at $1{ }^{\circ} \mathrm{C}$ and held at a core temperature of $1{ }^{\circ} \mathrm{C}$ for 16 days. At the end of the disinfestation treatment, the fruit were removed to $20{ }^{\circ} \mathrm{C}$ to ripen.

Control fruit were either not hot water-treated or disinfected (un-treated), or hot water-treated only at $40{ }^{\circ} \mathrm{C}$ for $60 \mathrm{~min}$, or cold disinfested only, before ripening at $20{ }^{\circ} \mathrm{C}$.

The hot water treatment was carried out in a commercial fibreglass hot water dipping tank with 3001 of water. Uniform water distribution, and 
thus temperature within the bath, was achieved by pumping water (Onga model 444, Australia) over a $10 \mathrm{~kW}$ electric heater at the bottom of the bath. The pump inlet and outlet were near the bottom at opposite ends of the tank.

\subsection{Experiment 2}

Fruit were hot water-treated at $39,40,41$ or $42{ }^{\circ} \mathrm{C}$ for 20,25 or $30 \mathrm{~min}$, as above. Approximately $3 \mathrm{~h}$ after HWT, the fruit were placed in a $1{ }^{\circ} \mathrm{C}$ cold room and the fruit held at a core temperature of $1{ }^{\circ} \mathrm{C}$ for 16 days. All fruit were then treated with $80 \mathrm{mg} \mathrm{kg}^{-1}$ ethylene for 2.5 days at $16{ }^{\circ} \mathrm{C}$, then ripened at $16{ }^{\circ} \mathrm{C}$ to simulate recommended ripening conditions in New Zealand.

Control fruit were either ethylene-treated and ripened immediately after harvest as above, or cold disinfested only, or hot water-treated at $42{ }^{\circ} \mathrm{C}$ for $20 \mathrm{~min}$ only, before ethylene treatment and ripening.

A 400-1 stainless steel insulated tank was used for experiment 2. Water was pumped (Grundfos pumps; model UPS 32-80 B, Denmark) past a 10 $\mathrm{kW}$ in-line electric heating element, and into the tank via perforated PVC tubing (22 mm ID) arranged in a grid pattern in the base of the bath.

In both experiments, about 180 fruit were treated at the same time. Temperatures of the treatment water, and of fruit about $3 \mathrm{~mm}$ under the fruit surface, were recorded using $0.5 \times 80 \mathrm{~mm}$ type $\mathrm{T}$ thermocouples inserted into $0.8 \times 90 \mathrm{~mm}$ needles, and attached to a Newport Electronics 269-TC C1 08 recorder. The thermocouples were calibrated in an ice slurry and boiling water. Water temperatures during HWT deviated by no more that $0.2{ }^{\circ} \mathrm{C}$ from the set temperature throughout all treatments in both experiments. Typically, after $30 \mathrm{~min}$ at 38,40 and $42{ }^{\circ} \mathrm{C}$, the temperature about $2-3 \mathrm{~mm}$ under the skin was 33.6, 37.6 and $38.4{ }^{\circ} \mathrm{C}$, respectively.

\subsection{Quality assessments}

External fruit quality was assessed at removal from cold disinfestation or from ethylene treatment by recording the percentage of skin area with skin damage observed as a blackening of the skin. Nodule damage on the skin was rated as the percentage of the nodules with black colour. Fruit firmness was assessed by gentle hand pressure, and the days to eating soft (DTES) determined as the number of days from harvest or from removal from $1{ }^{\circ} \mathrm{C}$ to reach a hand pressure corresponding to a firmness of 4-6 N, as measured by an Instron Universal Testing Machine model 1122, fitted with an $8 \mathrm{~mm}$ hemispherical probe (probe penetration $2 \mathrm{~mm}$ ).

At the eating soft stage, skin colour was assessed as the percentage of the skin surface area with dark purple to black colour, and nodule damage was rated as above. Fruit were then cut longitudinally and peeled, and rated for the severity of body rots (caused mainly by Colletotrichum spp) as the percentage of the flesh with lesions. Stem rots severity (caused mainly by Dothiorella $\mathrm{spp}$ ) and the severity of the internal disorders of mesocarp discolouration (MD) and vascular browning (VB) (Swarts, 1985) were recorded as the percentage of the cut surface area affected. For disease identification, skin and flesh samples were taken from the advancing margin of representative lesions and incubated on potato dextrose agar with and without streptomycin (approx. $0.5 \%$ ) at $25{ }^{\circ} \mathrm{C}$ for $7-10$ days.

Each fruit was rated as having acceptable commercial external appearance 3 days after removal from $1{ }^{\circ} \mathrm{C}$ if there was less than $5 \%$ skin damage and less than $5 \%$ of damaged nodules combined. Fruit were considered to have acceptable internal quality if there was $5 \%$ less than rots or internal disorders combined.

\subsection{Experimental design and statistical analysis}

Twenty fruit were used from each of the three treatment replicates (grower and orchard block for experiment 1 and 2, respectively). Results were analysed with Genstat 4.1 (4th ed.) using general analysis of variance with the grower or orchard block as the block. The percentage ratings data were angular transformed before analysis, and either back-transformed for tables, or plotted on an angular scale for graphs. The protected least significant difference (L.S.D.) procedure at $P=$ 
0.05 was used to test for differences in treatment means. Only significant differences at $P=0.05$ are described, unless stated otherwise.

\section{Results}

\subsection{Experiment 1}

Skin damage after disinfestation occurred as black patches on the skin, usually associated with mechanical damage to the raised 'nodules'. In more severe cases, the damage spread to the adjoining 'valleys' in the skin to form larger areas of damage. Symptoms were occasionally obvious on ripe fruit as sunken, dark brown areas.

There was no skin damage on fruit ripened immediately after harvest, either without or after HWT (Table 1). Disinfestation without HWT resulted in about $15 \%$ damage to the skin at removal from disinfestation. All HWTs significantly reduced skin damage, with the least damage obtained with $40{ }^{\circ} \mathrm{C}$ for $60 \mathrm{~min}$, and $42{ }^{\circ} \mathrm{C}$ for 20 $\min$.
Body rots severity in ripe fruit was generally low in all treatments (Table 1). Disinfestation alone increased body rots severity compared to untreated fruit and HWT fruit only. Hot water treatments at 38 and $40{ }^{\circ} \mathrm{C}$, and at $42{ }^{\circ} \mathrm{C}$ for 20 min prior to disinfestation significantly reduced rots severity. Treatment at $42{ }^{\circ} \mathrm{C}$ for $40 \mathrm{~min}$ before disinfestation had similar body rots severity as disinfestation alone.

Stem rots, MD and VB severity was low, with no significant effect of HWT or disinfestation on severity (data not presented).

Untreated fruit were eating soft at day 10. Fruit from all other treatments reached the eating soft stage within 6-7 days of removal from disinfestation, with no significant difference between HWT and disinfested controls (Table 1).

Fruit not hot water-treated, and those treated at $42{ }^{\circ} \mathrm{C}$ for $40 \mathrm{~min}$ then disinfested, had the least dark colour on the ripe fruit skin (Table 1). The 38 and $40{ }^{\circ} \mathrm{C}$ treatments increased the percentage of the skin with dark colour compared to disinfestation alone, but there was little effect of treatment duration.

Table 1

Experiment 1; the number of days after harvest (for no disinfestation) or after removal from disinfestation for 'Hass' avocado fruit to reach the eating soft stage, the percentage area of the skin with skin damage at removal from disinfestation, the percentage of the cut flesh surface area with body rots and the percentage of the skin with dark purple-black colour when ripe, either without or following hot water treatment $\left(38-42{ }^{\circ} \mathrm{C}\right.$ for $\left.20-60 \mathrm{~min}\right)$ or disinfestation $\left(1{ }^{\circ} \mathrm{C} \text { for } 16 \text { days }\right)^{\mathrm{a}}$

\begin{tabular}{|c|c|c|c|c|}
\hline \multirow[t]{2}{*}{ Hot water treatment } & \multirow[t]{2}{*}{ Days to eating soft } & \multicolumn{3}{|c|}{$\%$ of area with } \\
\hline & & Skin damage & Body rots in flesh & Black/purple \\
\hline \multicolumn{5}{|c|}{ No disinfestation (No storage, ripened at $20^{\circ} \mathrm{C}$ ) } \\
\hline None & $9.9 \mathrm{c}$ & $0.00 \mathrm{a}(0.0)$ & $0.12 \mathrm{bc} \quad(1.4)$ & $1.33 \mathrm{a} \quad(94.3)$ \\
\hline $40{ }^{\circ} \mathrm{C}, 60 \mathrm{~min}$ & $6.9 \mathrm{ab}$ & $0.00 \mathrm{a}(0.0)$ & $0.04 \mathrm{a} \quad(0.2)$ & $1.47 \mathrm{~cd}(99.0)$ \\
\hline \multicolumn{5}{|c|}{ Disinfestation $\left(1{ }^{\circ} \mathrm{C}\right.$ for 16 days, ripened at $\left.20^{\circ} \mathrm{C}\right)$} \\
\hline None & $6.7 \mathrm{ab}$ & $0.40 \mathrm{e}(15.2)$ & $0.31 \mathrm{~d} \quad(9.3)$ & $1.29 \mathrm{a} \quad(92.3)$ \\
\hline $38{ }^{\circ} \mathrm{C}, 30 \mathrm{~min}$ & $6.4 \mathrm{a}$ & $0.36 \mathrm{~d}(12.4)$ & $0.17 \mathrm{bc} \quad(2.9)$ & $1.49 \mathrm{~cd}(99.3)$ \\
\hline $38{ }^{\circ} \mathrm{C}, 60 \mathrm{~min}$ & $6.8 \mathrm{a}$ & $0.34 \mathrm{~d}(11.1)$ & $0.18 \mathrm{c} \quad(3.2)$ & $1.46 \mathrm{~cd}(98.8)$ \\
\hline $40{ }^{\circ} \mathrm{C}, 30 \mathrm{~min}$ & $6.4 \mathrm{a}$ & $0.30 \mathrm{c}(8.7)$ & $0.12 \mathrm{abc}(1.4)$ & $1.53 \mathrm{~d} \quad(99.8)$ \\
\hline $40{ }^{\circ} \mathrm{C}, 60 \mathrm{~min}$ & $6.4 \mathrm{a}$ & $0.29 \mathrm{c}(8.2)$ & $0.09 \mathrm{ab} \quad(0.8)$ & $1.50 \mathrm{~d} \quad(99.5)$ \\
\hline $42{ }^{\circ} \mathrm{C}, 20 \mathrm{~min}$ & $7.0 \mathrm{~b}$ & $0.26 b(6.6)$ & $0.17 \mathrm{c} \quad(2.9)$ & $1.41 \mathrm{bc}(97.4)$ \\
\hline $42{ }^{\circ} \mathrm{C}, 40 \mathrm{~min}$ & $7.1 \mathrm{~b}$ & $0.30 \mathrm{c}(8.7)$ & $0.26 \mathrm{~d} \quad(6.6)$ & $1.35 \mathrm{ab}(95.2)$ \\
\hline L.S.D. & 0.08 & 0.02 & 0.08 & 0.07 \\
\hline
\end{tabular}

\footnotetext{
${ }^{\text {a }}$ Means followed by the same letter in each column are not significantly different at $P=0.05(n=20)$. The percentage data are angular transformed, with back-transformed means presented in brackets.
} 
Table 2

Experiment 2; the number of days after harvest (for no disinfestation) or after removal from disinfestation for 'Hass' avocado fruit to reach the eating soft stage, the percentage of the cut flesh surface area with either vascular browning or mesocarp discolouration, and the percentage of ripe fruit with acceptable internal quality ${ }^{\mathrm{a}}$ either without or following hot water treatment $\left(39-42{ }^{\circ} \mathrm{C}\right.$ for 20-30 min) or disinfestation $\left(1{ }^{\circ} \mathrm{C} \text { for } 16 \text { days }\right)^{\mathrm{b}}$

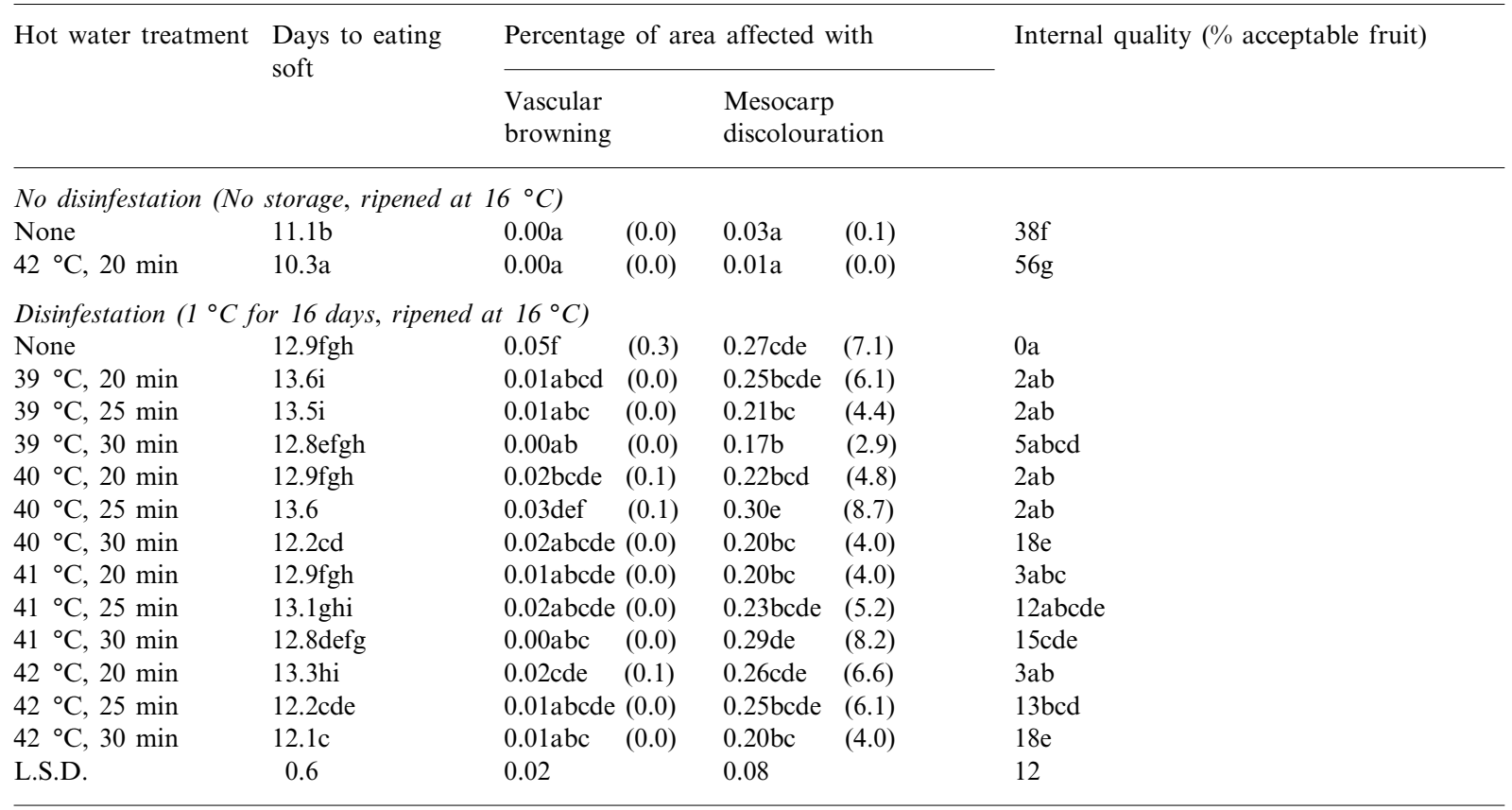

\footnotetext{
${ }^{\text {a }}$ Based on less than $5 \%$ of the flesh with rots or flesh disorders combined.

${ }^{\mathrm{b}}$ Means followed by the same letter in each column are not significantly different at $P=0.05(n=20)$. Vascular browning and mesocarp discolouration data are angular transformed, with back-transformed means presented in brackets.
}

\subsection{Experiment 2}

Hot water treatment alone reduced the DTES compared to no treatment (Table 2). However, disinfestation increased the DTES by up to 3 days, compared to untreated or HWT fruit. There was little difference in DTES between the HWT temperatures, with little consistent effect of duration across the treatment temperatures.

The HWT effects on skin damage was similar to Experiment 1 (Fig. 1). The patterns of treatment effects were similar at removal from disinfestation and after 3 days, but damage was much more severe after 3 days (about $80 \%$ of the skin damaged after disinfestation with no HWT). All HWT treatments reduced severity, with the lowest severity of about $1 \%$ occurring with $41{ }^{\circ} \mathrm{C}$ for 25 or $30 \mathrm{~min}$, or $42{ }^{\circ} \mathrm{C}$ for 25 or $30 \mathrm{~min}$.
Damage on the nodules was more obvious after disinfestation than before treatment, but there was little treatment effect on the percentage of the nodules that were damaged (data not presented). There was little visible nodule damage on eating soft fruit.

Body rots severity in ripe fruit was generally higher in disinfested fruit than in the non-disinfested fruit (Fig. 2). Hot water treatment significantly reduced body rots severity, with higher temperatures up to $41{ }^{\circ} \mathrm{C}$, and longer times having the greatest effect. The lowest severity in the disinfested fruit occurred with $41{ }^{\circ} \mathrm{C}$ for $30 \mathrm{~min}$, and $42{ }^{\circ} \mathrm{C}$ for $25 \mathrm{~min}$. Stem rots severity was low in all treatments (on average less than $1 \%$ of the flesh area affected), but was reduced by HWT at 40 and $41{ }^{\circ} \mathrm{C}$, compared to disinfestation alone (Fig. 2). 
Vascular browning severity was low (Table 2), and severity was higher after disinfestation alone compared to no treatment. Most of the HWTs significantly reduced VB compared to disinfestation alone, but there was no consistent effect between the HWTs. Mesocarp discolouration severity was increased by disinfestation, but HWT generally did not reduce severity.

The percentage of the ripe skin with 'natural ripening' colour (purple to black) at eating soft was low (Fig. 3). Disinfestation alone increased this percentage and HWT before disinfestation reduced it, due mainly to the effects of these treatments on skin damage. Higher temperatures and longer durations reduced the percentage of the skin with dark colour.

All HWTs except $39{ }^{\circ} \mathrm{C}$ for $20 \mathrm{~min}$ increased the percentage of fruit with no more than $5 \%$ of

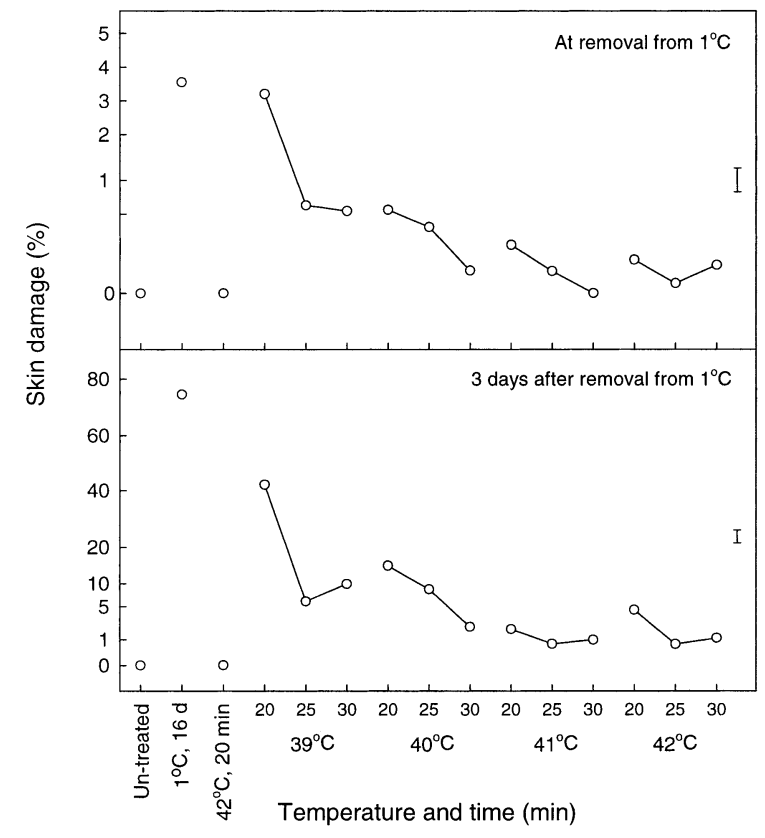

Fig. 1. The percentage of the skin of 'Hass' avocado fruit with damage following either no additional treatment (un-treated), or disinfesting at $1{ }^{\circ} \mathrm{C}$ for 16 days without hot water treatment (HWT), or HWT at $42{ }^{\circ} \mathrm{C}$ for $20 \mathrm{~min}$ without subsequent disinfestation, or HWT at $39-42{ }^{\circ} \mathrm{C}$ for $20-30 \mathrm{~min}$, then disinfesting at $1{ }^{\circ} \mathrm{C}$ for 16 days (experiment 2). Fruit were assessed at removal from disinfestation or after 3 days at $16{ }^{\circ} \mathrm{C}$. The vertical bar indicates significant difference of means at L.S.D. of $P \leq 0.05$.

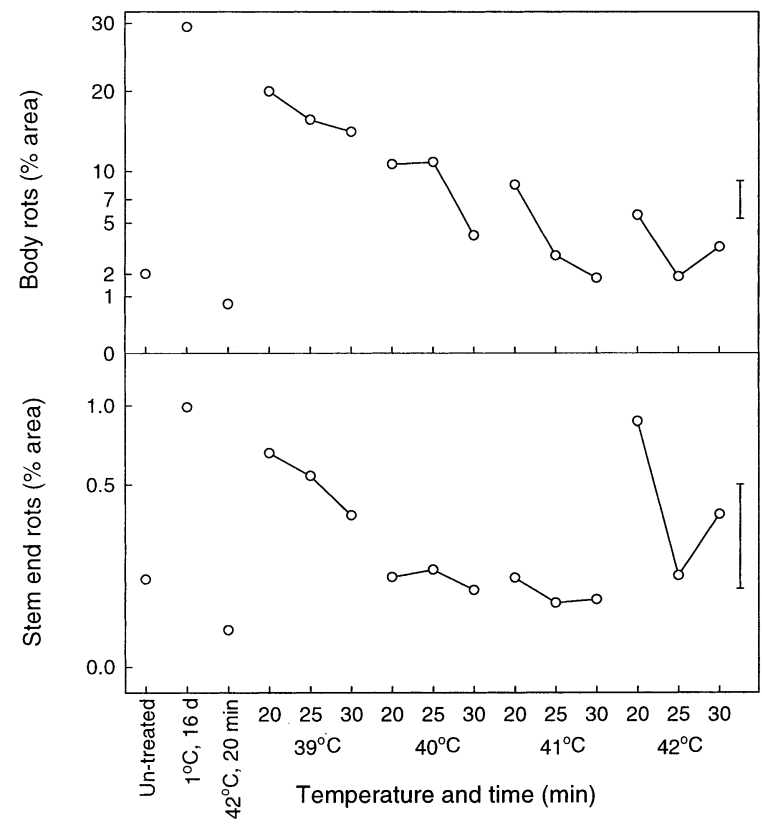

Fig. 2. The percentage of the flesh of ripe 'Hass' avocado fruit with body rots or stem rots following either ripening without any additional treatment (un-treated), or disinfesting at $1{ }^{\circ} \mathrm{C}$ for 16 days without hot water treatment (HWT), or HWT at $42{ }^{\circ} \mathrm{C}$ for $20 \mathrm{~min}$ without subsequent disinfestation, or HWT at $39-42{ }^{\circ} \mathrm{C}$ for $20-30 \mathrm{~min}$, then disinfesting at $1{ }^{\circ} \mathrm{C}$ for 16 days (experiment 2). The vertical bar indicates significant difference of means at L.S.D. of $P=0.05$.

the skin area with damage at removal from $1{ }^{\circ} \mathrm{C}$ and after 3 days at $16{ }^{\circ} \mathrm{C}$ (Fig. 4). Treatment conditions of $40{ }^{\circ} \mathrm{C}$ for $30 \mathrm{~min}$ and above generally gave the best results after 3 days. The percentage of externally acceptable fruit after 3 days (based on less than $5 \%$ of the skin with damage and less than $5 \%$ of damaged nodules combined) was also improved with all HWTs, especially with longer durations (Fig. 5). Treatments at $41{ }^{\circ} \mathrm{C}$ for $25-30 \mathrm{~min}$ and $42{ }^{\circ} \mathrm{C}$ for $25 \mathrm{~min}$ resulted in the highest percentage of acceptable fruit.

All fruit were unacceptable internally after disinfestation alone (Table 2). Hot water treatment without disinfestation increased the percentage of internally acceptable fruit compared to no treatment. Hot water treatment at 40 and $41{ }^{\circ} \mathrm{C}$ for $30 \mathrm{~min}$, and $42{ }^{\circ} \mathrm{C}$ for 25 and $30 \mathrm{~min}$ also significantly increased internal fruit acceptability com- 
pared to disinfestation alone. This effect was mainly due to reduction in rots and MD.

\section{Discussion}

The results of this study confirm that hot water treatments around $40{ }^{\circ} \mathrm{C}$ suggested by Woolf (1997) can have important commercial application for avocado fruit, with similar effects in fruit from several seasons and production locations.

Reduction in chilling damage on the skin following hot water or hot air has been observed in grapefruit (Porat et al., 2000) and avocado (Woolf et al., 1995). In the current experiments, damage to the raised nodules of the skin of 'Hass' avocado appeared to contribute to skin damage after disinfestation. When severity was low, most of the damage was restricted to damaged nodules or immediately adjacent areas, while increased severity was associated with damage spreading to the adjacent lower areas of the skin. This may be related to increased moisture loss from the damaged nodules, possibly due to similar mechanisms to the increased chilling injury observed during storage of a range of fruit under lower humidities (Cutting and Wolstenholme, 1992; Paull, 1999).

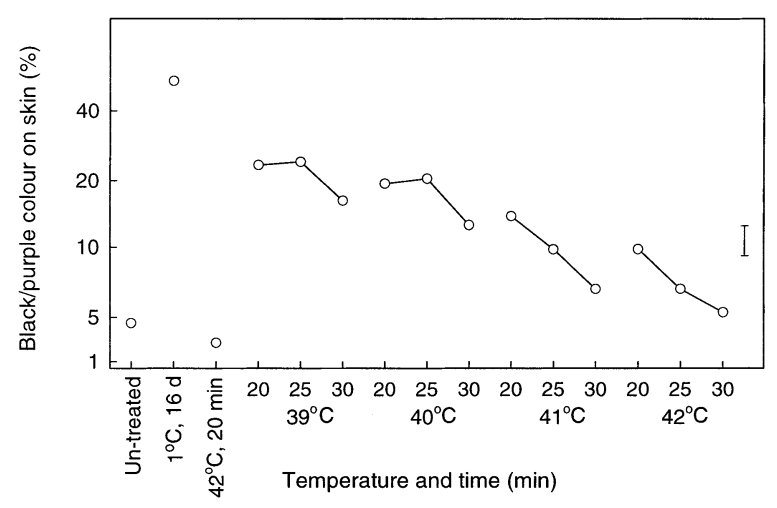

Fig. 3. The percentage of the skin of ripe 'Hass' avocado fruit with dark purple-black colour following either ripening without any additional treatment (un-treated), or disinfesting at $1{ }^{\circ} \mathrm{C}$ for 16 days without hot water treatment (HWT), or HWT at $42{ }^{\circ} \mathrm{C}$ for 20 min without subsequent disinfestation, or HWT at $39-42{ }^{\circ} \mathrm{C}$ for $20-30 \mathrm{~min}$, then disinfesting at $1{ }^{\circ} \mathrm{C}$ for 16 days (experiment 2). The vertical bar indicates significant difference of means at L.S.D. of $P=0.05$.

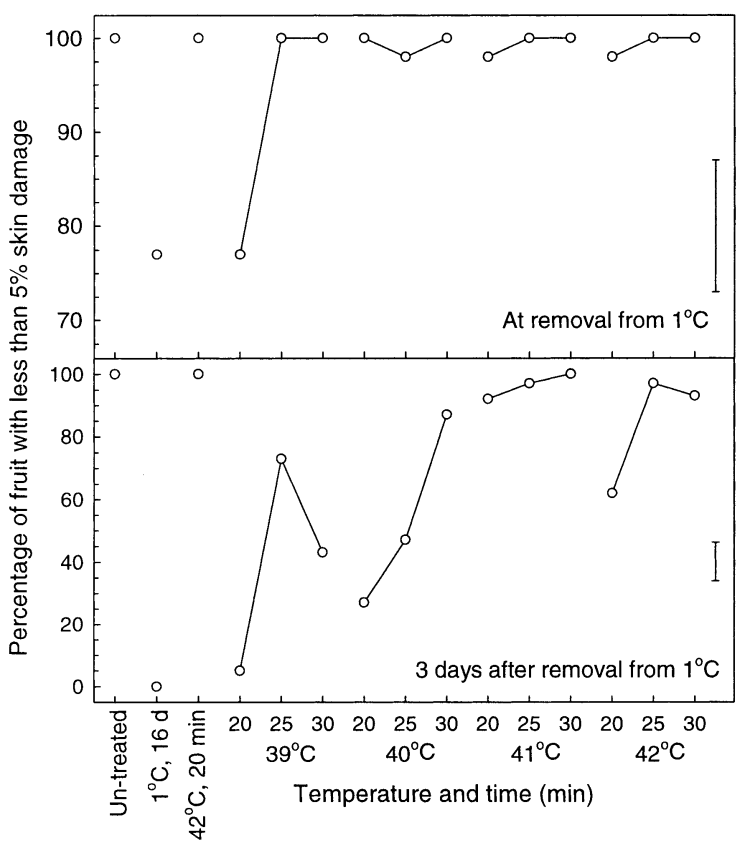

Fig. 4. The percentage of 'Hass' avocado fruit with less than $5 \%$ of the skin surface area affected by skin damage following either ripening without any additional treatment (un-treated), or disinfesting at $1{ }^{\circ} \mathrm{C}$ for 16 days without hot water treatment (HWT), or HWT at $42{ }^{\circ} \mathrm{C}$ for $20 \mathrm{~min}$ without subsequent disinfestation, or HWT at $39-42{ }^{\circ} \mathrm{C}$ for $20-30 \mathrm{~min}$, then disinfesting at $1{ }^{\circ} \mathrm{C}$ for 16 days (experiment 2). Fruit were assessed at removal from disinfestation and after 3 days at $16{ }^{\circ} \mathrm{C}$. The vertical bar indicates significant difference of means at L.S.D. of $P=0.05$.

Thus, other approaches such as reducing nodule damage during harvesting and sorting, and using fruit surface coatings (Kritzinger and Kruger, 1997), may also reduce damage after disinfestation.

Research on other commodities indicates that temperatures between 38 and $42{ }^{\circ} \mathrm{C}$ are generally the most effective for conditioning of fruit to subsequent heat or cold treatments (Lurie, 1998). In avocado, hot air treatments between 34 and $46{ }^{\circ} \mathrm{C}$ showed that a temperature of $38-40{ }^{\circ} \mathrm{C}$ resulted in the greatest reduction in external chilling injury (Woolf et al., 1995). The current results indicate optimum treatments for 'Hass' avocado conditioning for cold disinfestation are about $41{ }^{\circ} \mathrm{C}$ for about $20-30 \mathrm{~min}$, or potentially $42{ }^{\circ} \mathrm{C}$ for $20 \mathrm{~min}$. The fact that these temperatures are 
higher than that of Woolf et al. (1995) may be due to the significantly longer treatment times inherent in hot air heat treatments. There was no evidence that this optimum temperature range was different between the two experiments carried out here. In contrast, Kritzinger and Kruger (1997) suggested that the best treatment for reducing chilling injury (CI) in 'Hass' can vary from $30{ }^{\circ} \mathrm{C}$ for $90 \mathrm{~min}$ to $42{ }^{\circ} \mathrm{C}$ for $30 \mathrm{~min}$ for fruit harvested at different times and from several locations. Production district and harvest date may explain some of this variation in treatment response (Kritzinger and Kruger, 1997; Kritzinger et al., 1998), but responses are not always consistently related to maturity based on harvest date or percentage moisture in the flesh (Grové et al., 2000). Other aspects of the growing conditions may influence fruit responses, since sun-exposed avocado fruit can have greater tolerance to heat and cold (Woolf et al., 1999).

In several studies, HWT reduced CI after storage but did not eliminate it, and the responses were variable (Kritzinger and Kruger, 1997; Kritzinger et al., 1998; Grové et al., 2000). As a result, Grové et al. (2000) concluded that HWT was not a commercially viable treatment. However, it is possible that the shorter duration of $5 \mathrm{~min}$ at $46{ }^{\circ} \mathrm{C}$ used by Grové et al. (2000) was insufficient to overcome the physiological differences between lines of fruit during HWT.

The optimum HWT temperatures for minimum rots severity were similar to those for minimum skin damage in both experiments. This may be due to a direct effect on inoculum, since about $43 \mathrm{~min}$ at $43{ }^{\circ} \mathrm{C}$ resulted in $90 \%$ death of C. gloeosporioides (Chan et al., 1996). However, dipping 'Hass' fruit in Paraquat ${ }^{\circledR}$ resulted in similar skin damage symptoms to that observed after cold disinfestation, and diseases were more severe in the flesh below the damaged skin (Hofman, unpublished results). This, and the fact that those treatments that resulted in more skin damage generally had higher disease severity, suggests it is more likely that HWT reduced rots through reduced skin damage and improved ability to retard disease development.

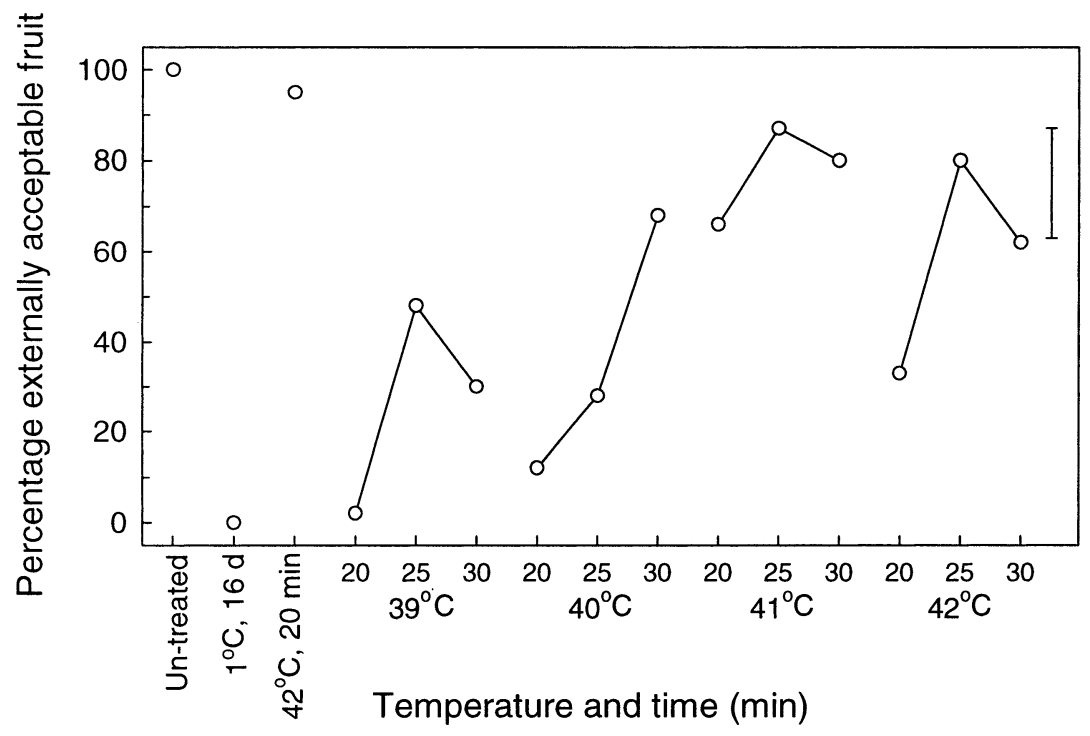

Fig. 5. The percentage of 'Hass' avocado fruit with acceptable external quality (no more than $5 \%$ of the fruit surface area with skin damage and less than $5 \%$ of damaged nodules combined) 3 days after removal from disinfestation with either no additional treatment (un-treated), or disinfesting at $1{ }^{\circ} \mathrm{C}$ for 16 days without hot water treatment (HWT), or HWT at $42{ }^{\circ} \mathrm{C}$ for 20 min without subsequent disinfestation, or HWT at $39-42{ }^{\circ} \mathrm{C}$ for $20-30 \mathrm{~min}$, then disinfesting at $1{ }^{\circ} \mathrm{C}$ for 16 days (experiment 2 ). The vertical bar indicates significant difference of means at L.S.D. of $P=0.05$. 
Such responses can be mediated through the ability of heat treatments to stabilise cell membranes, induce PR proteins such as chitinase, inhibit the synthesis of cell wall hydrolysing enzymes, stimulate the production of antifungal compounds, or reduce the decrease in antifungal compounds present in harvested fruit (Schirra et al., 2000). The latter mechanism could be involved in heat responses observed in the present studies. High $\mathrm{CO}_{2}$ concentrations after harvest can maintain antifungal concentrations in the skin, while $55{ }^{\circ} \mathrm{C}$ treatment for $10 \mathrm{~min}$ delayed the decrease in antifungal concentrations generally observed after harvest (Prusky and Keen, 1993). It is feasible that milder heat treatments could have a similar affect on antifungal concentrations as $\mathrm{CO}_{2}$, as well as retarding their possible decrease during disinfestation and subsequent ripening because of improved skin health.

The lower ripening temperatures used in the second experiment can reduce fruit rots (Hopkirk et al., 1994), but probably contributed to the poor purple-black skin colour on ripe fruit (Hofman, unpublished results). The skin colour of eating soft 'Hass' fruit is important, since poor skin colour in ripe fruit can result in consumption being delayed until full purple/black colour is obtained. By this stage the fruit is often over-ripe and heavily diseased, resulting in consumer dissatisfaction (Ledger and Barker, 1995). Further examination of postharvest treatments is required to balance the need to minimise rots and optimise 'Hass' skin colour.

These results confirm that HWT of 'Hass' avocado fruit will improve both external and internal quality during commercial disinfestation for fruit fly. However, further investigations are required on production and/or postharvest factors contributing to the varied responses discussed, and whether the heat treatments reduce efficacy of the cold disinfestation treatment because of insect conditioning.

\section{Acknowledgements}

We thank Jenny Barker for technical assistance, R. Simpson for supply of fruit, and the Depart- ment of Primary Industries, Queensland for financial support for this project.

\section{References}

Chan, H.T. Jr, Nishijima, K.A., Taniguchi, M.H., Linse, E.S., 1996. Thermal death kinetics of some common postharvest pathogens of papaya. HortScience 31, 998-1002.

Chervin, C., Kulkarni, S., Kreidl, S., Birrell, F., Glenn, D., 1997. A high temperature/low oxygen pulse improves cold storage disinfestation. Postharvest Biol. Technol. 10, 239245.

Cutting, J.G.M., Wolstenholme, B.N., 1992. Maturity and water loss effects on avocado (Persea americana Mill.) postharvest physiology in cool environments. J. Hort. Sci. 67, 569-575.

Florissen, P., Ekman, J.S., Blumenthal, C., McGlasson, W.B., Conroy, J., Holford, P., 1996. The effects of short heattreatments on the induction of chilling injury in avocado fruit (Persea americana Mill). Postharvest Biol. Technol. 8, 129-141.

Grové, T., De Beer, M.S., Steyn, W.P., 2000. Further evaluation of heat shock treatments to develop tolerance to quarantine cold treatments. S. Afr. Avocado Growers' Assoc. Yearbook 23, 103-108.

Hallman, G.J., 1999. Ionizing radiation quarantine treatments against tephritid fruit flies. Postharvest Biol. Technol. 16, 93-106.

Heather, N.W., Whitfort, L., McLauchlan, R.L., Kopittke, R., 1996. Cold disinfestation of Australian mandarins against Queensland fruit fly (Diptera: Tephritidae). Postharvest Biol. Technol. 8, 307-315.

Hofman, P.J., Vuthapanich, S., Klieber, A., Whiley, A.W., Simons, D.H., 1998. Effect of locality, irrigation and paclobutrazol on quality of 'Hass' avocado. In: Coates, L.M., Hofman, P.J., Johnson, G.I. (Eds.), Disease Control and Storage Life Extension in Fruit, Chiang Mai, May 1997. ACIAR, Canberra, pp. 67-76.

Hopkirk, G., White, A., Beever, D.J., Forbes, S.K., 1994. Influence of postharvest temperatures and the rate of fruit ripening on internal postharvest rots and disorders of New Zealand 'Hass' avocado fruit. New Zealand J. Crop Hort. Sci. 22, 305-311.

Jacobi, K.K., Giles, J.E., 1997. Quality of Kensington mango (Mangifera indica Linn.) fruit following combined vapour heat disinfestation and hot water disease control treatments. Postharvest Biol. Technol. 12, 285-292.

Jacobi, K.K., Wong, L.S., Giles, J.E., 1996. Conditioning with hot air reduces heat damage caused to 'Kensington' mango (Mangifera indica Linn.) by hot water disinfestation treatment. Aust. J. Exp. Agric. 36, 507-512.

Jessup, A.J., 1994. Quarantine disinfestation of 'Hass' avocados against Bactrocera tryoni (Diptera: Tephritidae) with a hot fungicide dip followed by cold storage, J. Econ. Entomol. 127-130. 
Klein, J., Lurie, S., 1992. Heat treatments for improved postharvest quality of horticultural crops. HortTechnology 2, 316-320.

Kritzinger, M., Kruger, F.J., 1997. Preliminary results on the evaluation of hot water heatshock treatment of South African avocados. S. Afr. Avocado Growers' Assoc. Yearbook 20, 1-5.

Kritzinger, M., Kruger, F.J., Bezuidenhout, M., 1998. Further evaluation of hot water/air heatshock treatments of South African avocados. S. Afr. Avocado Growers' Assoc. Yearbook 21, 93-96.

Ledger, S.N., Barker, L.R., 1995. Black avocados — the inside story. In: Proceedings of the Australian Avocado Growers Federation Conference 'The Way Ahead', pp. 71-77.

Lurie, S., Klein, J., 1992. Ripening characteristics of tomatoes stored at $12{ }^{\circ} \mathrm{C}$ and $2{ }^{\circ} \mathrm{C}$ following a prestorage heat treatment. Sci. Hortic. 51, 55-64.

Lurie, S., 1998. Postharvest heat treatments. Postharvest Biol. Technol. 14, 257-269.

Nyanjage, M.O., Wainwright, H., Bishop, C.F.H., 1998. The effects of hot-water treatments in combination with cooling and/or storage on the physiology and disease of mango fruits (Mangifera indica Linn.). J. Hort. Sci. Biotechnol. 73, 589-597.

Paull, R.E., 1999. Effect of temperature and relative humidity on fresh commodity quality. Postharvest Biol. Technol. 15, 263-277.

Porat, R., Pavoncello, D., Peretz, J., Weiss, B., Daus, A., Cohen, L., Ben-Yehoshua, S., Fallik, E., Droby, S., Lurie,
S., 2000. Induction of resistance to Penicillium digitatum and chilling injury in 'Star Ruby' grapefruit by a short hot-water rinse and brushing treatment. J. Hort. Sci. Biotechnol. 75, 428-432.

Prusky, D., Keen, N., 1993. Involvement of preformed antifungal compounds in the resistance of subtropical fruits to fungal decay. Plant Dis. 77, 114-119.

Sanxter, S.S., Nishijima, K.A., Chan, H., 1994. Heat-treating 'sharwil' avocado for cold tolerance in quarantine cold treatments. HortScience 29, 1166-1168.

Schirra, M., D’hallewin, G., Ben-Yehoshua, S., Fallik, E., 2000. Host-pathogen interactions modulated by heat treatment. Postharvest Biol. Technol. 21, 71-85.

Swarts, D.H., 1985. Postharvest problems in avocados. Farming S. Afr. 1.3, 1-4.

Woolf, A.B., Lay-Yee, M., 1997. Pretreatments at $38{ }^{\circ} \mathrm{C}$ of 'Hass' avocado confer thermotolerance to $50{ }^{\circ} \mathrm{C}$ hot water treatments. HortScience 32, 705-708.

Woolf, A.B., Watkins, C.B., Bowen, J.G., Maindonald, J.H., Lay-Yee, M., Ferguson, I.B., 1995. Reducing external chilling injury in stored 'Hass' avocados with dry heat treatments. J. Am. Soc. Hort. Sci. 120, 1050-1056.

Woolf, A.B., Bowen, J.H., Ferguson, I.B., 1999. Preharvest exposure to the sun influences postharvest responses of 'Hass' avocado fruit. Postharvest Biol. Technol. 15, 143153.

Woolf, A.B., 1997. Reduction of chilling injury in stored 'Hass' avocado fruit by $38{ }^{\circ} \mathrm{C}$ water treatments. HortScience 32, 1247-1251. 